\title{
Cariologic Study of the Plant Species on the South- Western Gutai Mountains Pasture
}

\author{
Zorica VOȘGAN*, Roxana VIDICAN, Lucia MIHALESCU, Monica MARIAN, Stela JELEA, Oana MARE \\ ROŞCA, Anca DUMUȚA \\ North University Center at Baia Mare, Tehnical, University of Cluj-Napoca, Victoriei Street, No.76, \\ 430122, Baia Mare, Romania. \\ *corresponding author: zori_v13@yahoo.com
}

Bulletin UASVM series Agriculture 73(2)/2016

Print ISSN 1843-5246; Electronic ISSN 1843-5386

DOI 10.15835/buasvmcn-agr: 12418

\begin{abstract}
This paper presents karyology aspects of the diploid and polyploid species frequency on the mountain pastures in the southwestern Gutai Mountains as well as the calculation of the diploid index. The phytocoenosis of the five plant associations identified on pasture were studied: Violo declinatae-Nardetum, Simon 1966, Agrostietum stoloniferae, (Ujvárosi 1941) Burduja et al. 1956, Scirpetum sylvatici, Ralski 1931, Maloch 1935 em. Schwick 1944, Calthetum laetae, Krajina 1933, Campanulo abientinae-Vaccinietum myrtilli, (Buia et al. 1962) Boșcaiu 1971. Karyotypes were taken for all encountered vegetal species to achieve an accurate cytoaxonomic analysis. The frequency of polyploid species was found in the five vegetal associations that were identified and studied in karyology terms. The number of polyploids, comprised between $52.94-75 \%$, is ahead of the diploids number comprised between $25-43,75 \%$, in the vegetal associations phytocoenosis of the mountainous region. Diplo-polyploid plants and those with an unknown karyotype have lower participation. The calculated value of the diploid index decreases with the increasing of the altitude, with subunit values between $0.33-0.82$. Diploid index (DI) indicates instable character of vegetal formations of above-mentioned area, reflecting completely station conditions of the grassland. The genetic structure of the phytocoenosis and vegetal associations studied seen from the perspective of karyotypes, indicates a drop in the dioloid index value with the increasing of the anthropozoogen factor (excessive grazing).
\end{abstract}

Keywords: cariology, diploid index, polyploidy.

\section{INTRODUCTION}

In recent years numerous plants have been published in the field of cytotaxonomy which have been concerned with the cytological aspects of many species (Candan, 2013).

Understanding the distribution of genetic diversity of plant species exploited in mountain meadows is fundamental to their successful conservation, and to also develop appropriate strategies for preventing the loss of distinct populations.

The genetic structure of phytocoenosis will consider only the karyology issues. The presence of polyploids in various phytocenosis can reveal a number of phytogeographic regularities: this frequency has been found in a direct correlation with the age and conservative character of the studied vegetal associations (Boşcaiu, 1971, Cristea et al., 2004).

The composition of flora genetic types in the south-western region of Gutai Mountains has been analyzed taking into account only the karyology aspects, even if the genetic structure of the plant species included a wider range. Since 1928, Hagerup found a relationship between the karyology constitution and the geographic 
and altitude distribution of the plant species. Subsequent studies have confirmed this, thus increasing the number of polyploids ensure the species an increased resistance and much higher interspecific capacity, as it was stated over time by the great researchers in the field (Bănărescu and Boşcaiu, 1973, Cristea, 1991, Cristea et al. 2004).

The climate of the Gutai Mountains is generally cool with the annual average temperature of $2-4^{\circ} \mathrm{C}$ and relatively high rainfall. Acid $\mathrm{pH}$ soils generally predominate (districambosol) and the floristic composition is relatively meager, the nardet having the largest share, especially due to the acid substrate and developed muscinal layer (Voşgan et al. 2011, 2012). These ecological conditions and zooanthropic action have an effect on the frequent diploid and polyploid species of the studied area.

\section{MATERIALS AND METHODS}

The research was performed in the southeastern region of the Gutai Mountains, at an altitude of 1000-1300 meters, where, along zone vegetation, it is mostly woody vegetation and azonal vegetable formations such as coppices, weeds, shrubs, hydrophilic and hydrophobic formations. The sample surfaces, homogeneous in floristic terms, were chosen from the studied natural grasslands.

The phytosociological study was conducted through the method developed by Braun-Blanquet (1928) and adapted by Borza (1934), Borza et Boşcaiu (1965) to the features of the vegetation cover in our country. Karyotypes were taken for all encountered vegetal species to achieve an accurate cytoaxonomic analysis. Thus, the frequency of mountain meadows polyploids and the diploid significance index (I.D.) was followed. The diploid index, developed by Pignatii (1960), was calculated as the ratio between the number of diploid species $(\Sigma D)$ and that of polyploid species $(\Sigma \mathrm{P})$.

\section{RESULTS AND DISCUSSION}

Wooded areas alternating with lawns that are used as pastures for small ruminants (sheep and goats), on which species of acidophilus plants (e.g. Nardus strict, Deschampsia caespitosa, Vaccinium myrtillus, Vaccinium vitis-idaea, Campanula abientina, etc), are predominant in the south-west of the Gutai Mountains. Five plant associations prevailing in the established perimeter were identified subsequent to the performed research:

- Violo declinatae-Nardetum, Simon 1966 (A1)

- Agrostietum stoloniferae, (Ujvárosi 1941) Burduja et al. 1956 (A2)

- Scirpetum sylvatici, Ralski 1931, Maloch 1935 em. Schwick 1944 (A3)

- Calthetum laetae, Krajina 1933 (A4)

- Campanulo abientinae-Vaccinietum myrtilli, (Buia et al. 1962) Boșcaiu 1971 (A5)

The karyology analysis performed on the identified vegetal associations phytocoenoses, allowed the determining of the frequency of polyploids and diploids and the calculation of the diploid index value (Table 1).

The phytocoenosis set up by Nardus strica and Viola declinata (Violo declinatae-Nardetum)

Tab. 1. Kariologic structure of identified vegetal associations on the southwestern pasture of the Gutai Mountains

\begin{tabular}{|c|c|c|c|c|c|c|c|}
\hline \multirow{2}{*}{$\begin{array}{c}\text { Vegetal } \\
\text { associations }\end{array}$} & \multirow{2}{*}{$\begin{array}{l}\text { Total } \\
\text { sp }\end{array}$} & \multirow{2}{*}{$\begin{array}{c}\text { Known } \\
\text { karyotype } \\
\%\end{array}$} & \multicolumn{2}{|c|}{ Diploid } & \multicolumn{2}{|c|}{ Polyploid } & \multirow{2}{*}{ I.D. } \\
\hline & & & $\begin{array}{l}\text { Number of } \\
\text { species }\end{array}$ & $\%$ & $\begin{array}{c}\text { Number of } \\
\text { species }\end{array}$ & $\%$ & \\
\hline $\mathbf{A 1}$ & 22 & 90.9 & 5 & 25.0 & 15 & 75 & 0.33 \\
\hline A2 & 25 & 96 & 8 & 33.33 & 16 & 66.66 & 0.5 \\
\hline A3 & 21 & 90.47 & 6 & 31.57 & 13 & 68.42 & 0.46 \\
\hline A4 & 11 & 90.9 & 4 & 40.0 & 6 & 60.0 & 0.66 \\
\hline A5 & 17 & 94.11 & 7 & 43.75 & 9 & 52.94 & 0.82 \\
\hline
\end{tabular}




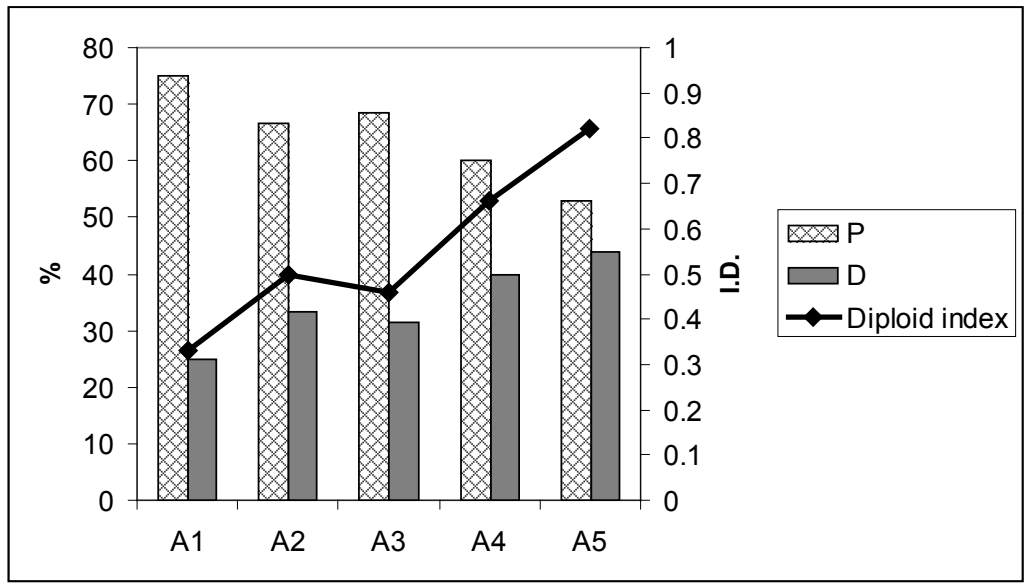

Fig. 1. The frequency of the diploid (D), polyploidy (P) species, and the value of the diploid index (I.D.).

on the mountain lawn shows a polyploid frequency of $75 \%$, while those dominated by Campanula abientina and Vaccinium myrtillus own 52.94\%. According to Boşcaiu, 1971, it was concluded that vegetable groups of the latest origin are richer in polyploids, having a much higher competitive capacity. It is known that the presence of Nardus stricta grasslands in the sub-alpine area of Romania are degraded from a floristic point of view, because the dominating species adapts to different levels of moisture and temperature, from $300 \mathrm{~m}$ to 2,200 m altitude, on acid, non-aerated, oligobasic, and oligotrophic soils (Maruşca et al., 2014). The value of the polyploids participation per the assembly of the five vegetal associations (64.60\%) suggests placing the associations in moderate continental climate regime, installed in a relatively recent historical period. As about the diploid species, they belong to a smaller percentage (25-43.75\%), which provides a favorable genetic potential for the future phyto-evolution.

The dominance of polyploid species was also reflected in the calculation of the diploid index, which normally decreases with the increasing of the altitude, being influenced by the climatic conditions, and in close correlation with the snow average duration. However, the plant groupings can be also influenced by the powerful pressures of some disturbing factors (intensive grazing, proximity of cities, etc.), that have a lower diploid index compared to those which evolved in stable environmental conditions (Cristea, 2004).
As can be seen in Figure 1, the variation of the diploid index shows a monotonic decrease in the plant associations identified on the grasslands of southwestern parts of the Gutai Mountains, with a sub-unitary value of $0.33-0.82$.

\section{CONCLUSION}

We analyzed the composition in genetic types of the flora in the southwestern region of the Gutai Mountains, where dominant vegetation associations were identified, taking into account the karyology issues.

The karyotype spectrum illustrates the dominance of polyploid species, with a frequency between $52.94-75 \%$, while the diploid species have a percentage of 25 to $43.75 \%$. Thus, the frequency of polyploids provides an increased resistance of the species in less stable ecological conditions, at altitudes above $1000 \mathrm{~m}$.

The genetic structure of the phytocoenosis and vegetal associations studied seen from the perspective of karyotypes, indicates a drop in the dioloid index value with the increasing of the anthropo-zoogen factor (excessive grazing). The calculation of the diploid index value presented a sub-unitary value, for all analyzed phytocoenosis.

\section{REFERENCES}

1. Bănărescu P, Boşcaiu N (1973). Biogeografie, perspectiva genetica si istorica. Ed. Stiintifica Bucuresti.

2. Boşcaiu N (1971). Flora si vegetatia Munților Tarcu, Glodeanu și Cernei. Ed. Academiei, București. 
3. Candan F (2013). Some Observations on Plant Karyology and Investigation Methods. Current Progress in Biological Research. ISBN 978-953-51-1097-2.

4. Cristea V (1991). Fitocenologie si vegetatia Romaniei. Indrumator de lucrari practice. Univ. Babes-Bolyai Cluj Napoca.

5. Cristea V, Gafta D, Pedrotti F (2004). Fitosociologie. Ed. Presa Universitara Clujeana, Cluj Napoca.

6. Marușca T, Dragomir N, Mocanu V, Blaj A., Tarjoc F, Dragomir C, Constantinescu S (2014). Effect of some Improvement Works on the Floristic Composition of the Vegetal Cover in Nardus stricta Grasslands. Scientific Papers: Animal Science and Biotechnologies 47 (1):144-150.
7. Vosgan Z, Vidican R, Jelea S, Marian M, Mihalescu L, Mare Roșca 0 (2011). Characterization of a Typical Districambosol Soil from the Gutai Mountains - North of Romania, Bulletin UASVM Agriculture, 68(1):384-387.

8. Voșgan Z, Vidican R, Marian M, Mihalescu L, Mare Roșca O, Dumuța A (2012). Research Regarding Vegetal Associations Specific To Mountain Meadow. Bulletin UASVM Agriculture 69(1):201-206. 